\title{
Analisis Faktor yang Mempengaruhi Kebijakan Hutang Emiten Pertanian di Bursa Efek Indonesia
}

\author{
Reza Ramadhany \\ Departemen Manajemen, Fakultas Ekonomi dan Manajemen, \\ Institut Pertanian Bogor \\ Kampus Darmaga Bogor 16680 \\ Mimin Aminah \\ Departemen Manajemen, Fakultas Ekonomi dan Manajemen, \\ Institut Pertanian Bogor \\ Kampus Darmaga Bogor 16680 \\ Yusrina Permanasari \\ Departemen Manajemen, Fakultas Ekonomi dan Manajemen, \\ Institut Pertanian Bogor \\ Kampus Darmaga Bogor 16680 \\ e-mail: yusrina.p@gmail.com
}

\begin{abstract}
In financial management perspective, corporate goal is to maximize shareholder or corporate value. The purpose of this study was to analyze the effect of institutional ownership (INST), asset structure (FAR), profitability (ROA), and corporate growth (GROWTH) on debt policy. This study used linear and multiple regression analysis. Significant test results of individual parameters (t statistical test) showed that significant value of INST variable $0.058<0.1(\alpha)$ and $-0.632(B)$, FAR $0.097<0.1(\alpha)$ and $1.019(8)$, ROA $0.043<0.1(\alpha)$ and $-1.198(B)$, and GROWTH $0.064<0.1(\alpha)$ and $0.972(B)$. The results showed that INST and ROA significantly and negatively affect debt policies, while FAR and GROWTH were significantly and positively affect on debt policies. Whereas, test result of simultaneous ( $F$ statistical test) showed that significant value was $0.010<0.1(\alpha)$ and the value of $F$ calculated was $4.184>2.184 F$ table. These results indicated that institutional ownership, asset structure, profitability, and corporate growth had a significant effect on debt policy simultaneously.

Keywords: institutional ownership, structure of assets, profitability, corporate growth
\end{abstract}

\begin{abstract}
ABSTRAK
Dalam perspektif manajemen keuangan tujuan perusahaan adalah memaksimalkan kekayaan pemegang saham atau memaksimalkan nilai perusahaan. Tujuan penelitian ini adalah menganalisis pengaruh faktor kepemilikan institusional (INST), struktur aset (FAR), profitabilitas (ROA), dan pertumbuhan perusahaan (GROWTH) terhadap kebijakan hutang. Penelitian ini menggunakan alat analisis Regresi Linier dan Regresi Berganda. Hasil uji signifikan parameter individual (uji statistik t) menunjukkan bahwa nilai signifikan variabel INST $0.058<0.1(\alpha)$ dan $-0.632(\beta)$, FAR $0.097<0.1(\alpha)$ dan $1.019(\beta)$, ROA $0.043<0.1(\alpha)$ dan $-1.198(\beta)$, dan GROWTH $0.064<0.1(\alpha)$ dan $0.972(\beta)$. Hasil tersebut menunjukkan INST dan ROA signifikan dan berhubungan negatif mempengaruhi kebijakan hutang, sedangkan FAR dan GROWTH signifikan dan berhubungan positif mempengaruhi kebijakan hutang. Sedangkan Hasil uji signifikan simultan (uji statistik F) menunjukkan bahwa nilai signifikan sebesar 0.010 $<0.1(\alpha)$ dan nilai F hitung $4.184>2.184 \mathrm{~F}$ tabel. Hasil ini menunjukkan bahwa faktor kepemilikan institusional, struktur aset, profitabilitas, dan pertumbuhan perusahaan secara bersama-sama memiliki pengaruh signifikan terhadap kebijakan hutang.

Kata Kunci: kepemilikan institusional, struktur aset, profitabilitas, pertumbuhan perusahaan
\end{abstract}




\section{Pendahuluan}

Pada umumnya memaksimalkan laba merupakan tujuan utama dari sebuah perusahaan. Namun dalam perspektif manajemen keuangan tujuan perusahaan bukanlah memaksimalkan laba, melainkan memaksimalkan kekayaan pemegang saham (stock holder's wealth) atau memaksimalkan nilai perusahaan (value of the firm) (Mardiyanto 2009). Perkembangan teori Modigliani dan Miller (proporsi MM I) mengatakan bahwa meningkatnya nilai perusahaan disebabkan oleh adanya peningkatan proporsi hutang dalam struktur modal perusahaan. Hal ini didasari oleh adanya biaya bunga yang muncul akibat penggunaan hutang, sehingga dapat menurunkan biaya pajak dan meningkatkan nilai perusahaan.

Hutang merupakan kewajiban perusahaan untuk membayar sejumlah uang atau barang kepada pihak yang memberikan pinjaman pada tanggal tertentu. Menurut Mardiyanto (2009), hutang jangka panjang bersifat tetap selama jangka waktu yang relatif panjang atau lebih dari satu tahun dan memiliki biaya hutang sehingga hutang jangka panjang sangat mempengaruhi nilai perusahaan. Penggunaan hutang secara berlebih oleh manajemen dapat menimbulkan risiko kebangkrutan yang tinggi. Adanya risiko kebangkrutan pada penggunaan hutang membuat manajemen perusahaan harus mempertimbangkan faktor-faktor yang mempengaruhi penggunaan hutang, di antaranya faktor kepemilikan institusional, faktor struktur aset, faktor profitabilitas, dan faktor pertumbuhan perusahaan (Yeniatie dan Destriana 2010).

Kepemilikan Institusional merupakan kepemilikan saham oleh pihak institusi lain berbentuk perusahaan atau lembaga dan blockholder, di mana blockholder adalah kepemilikan saham oleh perseorangan dengan nilai di atas $5 \%$ dan tidak masuk dalam jajaran manajemen perusahaan (Ismiyanti dan Hanafi 2003; Soesetio 2008). Kekuasaan besar pada kepemilikan institusional akan mengakibatkan munculnya kontrol yang ketat terhadap manajer, sehingga tindakan pendanaan hutang akan semakin ditekan.

Struktur aset merupakan penjabaran kekayaan aset yang dimiliki perusahaan, di mana salah satu akun dari struktur aset adalah aset tetap yang dapat dijadikan pertimbangan jaminan oleh kreditor dalam memberikan pinjaman. Menurut Brigham dan Gapenski (1996) serta Lestari (2001) bahwa secara umum perusahaan yang memiliki jaminan terhadap hutang akan lebih mudah mendapatkan hutang dari pada perusahaan yang tidak memiliki jaminan terhadap hutang.

Profitabilitas merupakan tingkat keuntungan bersih yang mampu dicapai perusahaan pada saat menjalankan operasionalnya. Apabila laba perusahaan tinggi, maka perusahaan dari pendanaan internal akan mencukupi untuk membiayai kebutuhan perusahaan. Apabila kebutuhan dana perusahaan belum mencukupi, perusahaan dapat menggunakan hutang sebagai salah satu alternatif pendanaan eksternal. Pertumbuhan perusahaan yang semakin meningkat, menandakan semakin meningkat pula dana yang dibutuhkan untuk membiayai operasional dan produksi perusahaan. Hal ini mendorong perusahaan untuk melakukan pengadaan sumber dana eksternal dengan menggunakan hutang dalam memenuhi kebutuhan pendanaan tersebut.

Penelitian ini menggunakan sampel pada perusahaan sektor pertanian yang terdaftar di Bursa Efek Indonesia (BEI) pada periode tahun 2007 sampai dengan tahun 2011. Hal ini dikarenakan perusahaan-perusahaan tersebut telah mengumumkan 
laporan keuangan secara terbuka kepada masyarakat. Berdasarkan peraturan menteri pertanian nomor: 06/Permentan/SR.130/2/2011, sektor pertanian adalah sektor yang berkaitan dengan budidaya tanaman pangan, hortikultura, perkebunan hijauan, pakan ternak, dan budidaya ikan dan/atau udang. Sektor pertanian merupakan sektor utama dalam penyerapan jumlah tenaga kerja terbesar di Inonesia. Pada periode tahun 2007 sampai dengan tahun 2011, berdasarkan data laporan keuangan melalui Indonesian Capital Market Electronic Library BEI, tingkat rasio hutang pada perusahaan pertanian memiliki tingkat rasio yang berfluktuatif dan bervariatif setiap tahun pada masingmasing perusahaan (www.idx.co.id diakses 07 Oktober 2012). Melihat tingkat pendanaan hutang yang bervariatif dan pentingnya sektor pertanian dalam penyerapan tenaga kerja terbesar di Indonesia, serta karakteristik pendanaan hutang yang memiliki manfaat nilai perlindungan pajak dan risiko kebangkrutan.

Tujuan penelitian ini adalah 1) Menganalisis faktor-faktor yang mempengaruhi kebijakan hutang pada perusahaan pertanian yang terdaftar di Bursa Efek Indonesia periode 2007-2011; 2) Menganalisis faktor kepemilikan institusional, struktur aset, profitabilitas, dan pertumbuhan perusahaan secara parsial mempengaruhi kebijakan hutang; 3) Menganalisis faktor kepemilikan institusional, struktur aset, profitabilitas, dan pertumbuhan perusahaan secara simultan mempengaruhi kebijakan hutang.

\section{Metode Penelitian}

Pada penelitian ini, dianalisis faktor-faktor yang mempengaruhi kebijakan hutang emiten pertanian yang terdaftar di Bursa Efek Indonesia diawali dengan menganalisis laporan keuangan perusahaan-perusahaannya, yang tediri dari kebijakan hutang, kepemilikan institusional, struktur aset, profitabilitas, dan pertumbuhan perusahaan. Lalu dilakukan analisis regresi untuk melihat hubungan kebijakan hutang dengan faktor-faktor lainnya. Hasil penelitian diharapkan dapat menjadi rekomendasi bagi perusahaan pertanian tersebut. Gambar kerangka pemikiran penelitian ini dapat dilihat pada Gambar 1.

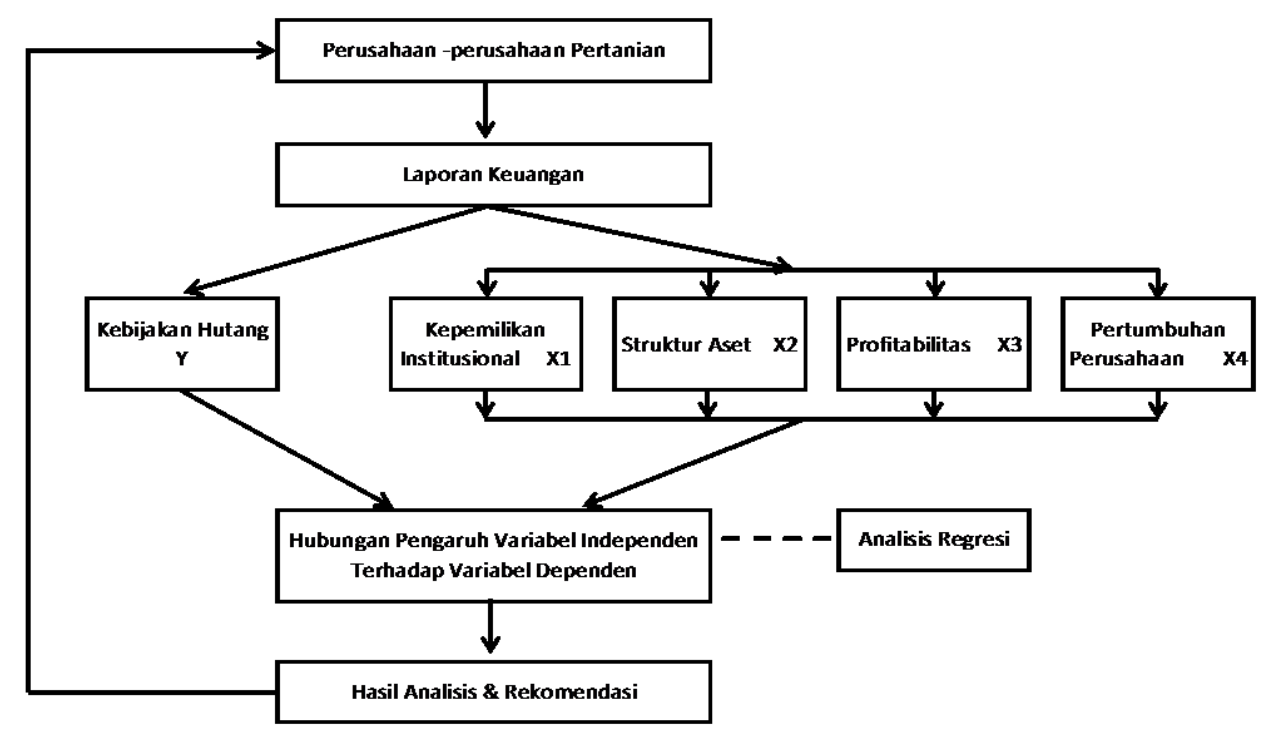

Gambar 1. Kerangka pemikiran penelitian 
Hipotesis sementara yang diajukan dalam penelitian ini adalah:

a. Hipotesis pertama

$\mathrm{H}_{0}$ : Kepemilikan Institusional (INST) tidak mempengaruhi Kebijakan Hutang (LDER).

$\mathrm{H}_{1}$ : Kepemilikan Institusional (INST) mempengaruhi Kebijakan Hutang (LDER).

b. Hipotesis kedua

$\mathrm{H}_{0}$ : Struktur Aset (FAR) tidak mempengaruhi Kebijakan Hutang (LDER).

$\mathrm{H}_{2}$ : Struktur Aset (FAR) mempengaruhi Kebijakan Hutang (LDER).

c. Hipotesis ketiga

$\mathrm{H}_{0}$ : Profitabilitas (ROA) tidak mempengaruhi Kebijakan Hutang (LDER).

$\mathrm{H}_{3}$ : Profitabilitas (ROA) mempengaruhi Kebijakan Hutang (LDER).

d. Hipotesis keempat

$\mathrm{H}_{0}$ : Pertumbuhan Perusahaan (GROWTH) tidak mempengaruhi Kebijakan Hutang (LDER).

$\mathrm{H}_{4}$ : Pertumbuhan Perusahaan (GROWTH) mempengaruhi Kebijakan Hutang (LDER).

e. Hipotesis kelima

$\mathrm{H}_{0}$ : Kepemilikan Institusional (INST), Struktur Aset (FAR), Profitabilitas (ROA), dan Pertumbuhan Perusahaan (GROWTH) secara bersama-sama tidak mempengaruhi Kebijakan Hutang (LDER).

$\mathrm{H}_{5}$ : Kepemilikan Institusional (INST), Struktur Aset (FAR), Profitabilitas (ROA), dan Pertumbuhan Perusahaan (GROWTH) secara bersama-sama mempengaruhi Kebijakan Hutang (LDER).

Penelitian ini memiliki dua variabel yaitu variabel dependen dan variabel independen, yaitu :

a. Variabel dependen $(\mathrm{Y})$.

Variabel dependen yang digunakan dalam penelitian ini adalah kebijakan hutang di mana dihitung dengan proksi long term debt to equity ratio (LDER) sebagai berikut:

$$
\text { LDER }=\frac{\text { Hutang Jangka Panjang }}{\text { Modal Sendiri }} \ldots \ldots \ldots \ldots \ldots \ldots \ldots
$$

b. Variabel independen $(X)$.

1. Variabel independen $X_{1}$ (kepemilikan institusional) pada penelitian ini diukur dengan proksi Institutional Investor (INST) yang dirumuskan sebagai berikut :

$$
\text { INST }=\frac{\text { Jumlah Saham yang dimilik oleh institusi }}{\text { Total Saham Beredar }} \text {. }
$$

2. Variabel independen $X_{2}$ (struktur aset) pada penelitian ini diukur dengan proksi Fixed Asset Ratio (FAR) yang dirumuskan sebagai berikut :

$$
\text { FAR }=\frac{\text { Fixed Asset }}{\text { Total Asset }}
$$

3. Variabel independen $X_{3}$ (profitabilitas) pada penelitian ini diukur dengan proksi Return on Asset (ROA) yang dirumuskan sebagai berikut: 


$$
\text { ROA }=\frac{\text { Laba Bersih }}{\text { Total Aset }}
$$

4. Variabel independen $\mathrm{X}_{4}$ (pertumbuhan perusahaan) pada penelitian ini diukur dengan proksi Rasio Pertumbuhan (Growth) yang dirumuskan sebagai berikut:

$$
\text { Growth }=\frac{\text { Total Aset }(\mathrm{t})-\text { Total Aset }(\mathrm{t}-1)}{\text { Total Aset }(\mathrm{t}-1)} \text {. }
$$

Jenis data yang dipergunakan dalam penelitian ini adalah data sekunder, berupa data penelitian yang diperoleh secara tidak langsung atau dengan media perantara. Data sekunder yang dibutuhkan bersumber dari website dan ICaMEL (Indonesian Capital Market Electronic Library) Bursa Efek Indonesia berupa laporan keuangan perusahaan sektor pertanian periode tahun 2007 sampai dengan tahun 2011.

Populasi dalam penelitian ini adalah semua perusahaan sektor pertanian yang terdaftar di Bursa Efek Indonesia sampai periode 2011. Sampel penelitian ini menggunakan teknik pengambilan sampel yang tidak memberi peluang yang sama bagi setiap anggota populasi untuk dipilih menjadi sampel, biasa disebut nonprobability sampling. Jenis nonprobability sampling yang digunakan adalah purposive sampling, di mana dalam penentuan sampel berdasarkan pertimbangan atau kriteria tertentu. Kriteria perusahaan yang akan menjadi sampel penelitian ini adalah sebagai berikut :

1. Perusahaan sektor pertanian yang terdaftar di Bursa Efek Indonesia.

2. Terdaftar di Bursa Efek Indonesia dari tahun 2007 atau sebelumnya sampai dengan tahun 2011.

Metode analisis data yang digunakan dalam penelitian ini adalah menggunakan model regresi linier berganda. Analisis regresi linier digunakan untuk menguji pengaruh antara variabel independen meliputi kepemilikan institusional (INST), struktur aset (FAR), profitabilitas (ROA) dan pertumbuhan perusahaan (GROWTH) terhadap kebijakan hutang (LDER) perusahaan sektor pertanian yang terdaftar di Bursa Efek Indonesia sebagai variabel dependen, baik secara parsial maupun secara bersama-sama/simultan. Model regresi linier yang digunakan adalah :

Keterangan:

$$
Y=\alpha+\beta_{1} X_{1}+\beta_{2} X_{2}+\beta_{3} X_{3}+\beta_{4} X_{4} \ldots \ldots \ldots \ldots \text { (6) }
$$

\footnotetext{
Y $\quad$ : Long Term Debt to Equity Ratio

$\alpha \quad$ : Konstanta

$\beta_{1,2,3,4,5}$ : Penaksir koefisien regresi

$\mathrm{X}_{1} \quad$ : Kepemilikan Institusional

$\mathrm{X}_{2} \quad$ : Struktur aset

$\mathrm{X}_{3} \quad$ : Profitabilitas

$\mathrm{X}_{4} \quad$ : Pertumbuhan perusahaan
}

Alat analisis regresi dalam pengujian hipotesis haruslah menghindari kemungkinan terjadinya penyimpangan asumsi klasik. Dalam penelitian ini asumsi klasik yang dianggap penting adalah memiliki distribusi normal, tidak terjadi multikolinieritas antar variabel independen, tidak terjadi heteroskedastisitas, dan tidak terjadi autokorelasi antar residual setiap variabel independen. Oleh karena itu, perlu dilakukan pengujian-pengujian sebagai berikut : 
1. Uji Normalitas

Uji normalitas bertujuan untuk menguji apakah dalam model regresi, variabel pengganggu atau residual memiliki distribusi normal (Ghozali 2005; Hapsari 2010).

2. Uji Multikolinearitas

Uji multikoliniearitas bertujuan untuk menguji apakah dalam suatu model regresi ditemukan adanya korelasi antar variabel bebas (independen).

3. Uji Autokorelasi

Uji autokorelasi bertujuan menguji apakah dalam model regresi linier ada korelasi antara kesalahan pengganggu pada periode t dengan kesalahan pengganggu pada periode $\mathrm{t}-1$ (sebelumnya).

4. Uji Heteroskedastisitas

Uji Heteroskedastisitas bertujuan untuk menguji apakah dalam model regresi ada ketidaksamaan varian dari residual suatu pengamatan lain (Ghozali 2005; Hapsari 2010).

Uji koefisien Determinasi $\left(R^{2}\right)$ pada intinya mengukur seberapa jauh kemampuan model dalam menerangkan variasi variabel dependen (Ghozali 2005; Hapsari 2010). Nilai koefisien determinasi adalah antara nol dan satu. Nilai $\mathrm{R}^{2}$ yang kecil berarti kemampuan variabel-variabel independen dalam menjelaskan variasi variabel independen hampir memberikan semua informasi yang dibutuhkan untuk memprediksi variasi variabel dependen.

Penggunaan koefisian determinasi $\left(R^{2}\right)$ memiliki kelemahan yakni timbulnya bias terhadap jumlah variabel independen yang dimasukkan ke dalam model. Setiap terjadi penambahan satu variabel independen, maka $R^{2}$ akan mengalami peningkatan pula tanpa memperdulikan variabel tersebut berpengaruh secara signifikan terhadap variabel dependen atau tidak. Oleh sebab itu, banyak peneliti menganjurkan untuk lebih menggunakan nilai adjusted $\mathrm{R}^{2}$ untuk mengevaluasi mana model regresi terbaik. Nilai adjusted $\mathrm{R}^{2}$ dapat naik atau turun apabila satu variabel independen ditambahkan ke dalam model.

Uji statistik $\mathrm{F}$ pada dasarnya menunjukkan apakah semua variabel independen atau bebas yang dimasukkan dalam model mempunyai pengaruh secara bersamasama terhadap variabel dependen atau terikat (Ghozali 2005; Hapsari 2010). Uji ini dilakukan dengan syarat sebagai berikut:

1. Jika $\mathrm{F}$ hitung $<\mathrm{F}$ table atau signifikan $\mathrm{F}>0.1$ maka $\mathrm{H}_{0}$ diterima. Artinya semua variabel independen secara bersama-sama tidak berpengaruh signifikan terhadap variabel dependen.

2. Jika $\mathrm{F}$ hitung $>\mathrm{F}$ table atau signifikansi $\mathrm{F}<0.1$ maka $\mathrm{H}_{0}$ ditolak. Artinya semua variabel independen secara bersama-sama berpengaruh signifikan terhadap variabel dependen.

Uji statistik t pada dasarnya menunjukan seberapa jauh pengaruh suatu variabel independen secara individual dalam menerangkan variasi variabel dependen (Ghozali 2005; Hapsari 2010). Pengujian dengan uji t atau t test yaitu membandingkan antara $t$ hitung dengan $t$ tabel. Uji ini dilakukan dengan syarat sebagai berikut:

1. Jika $t$ hitung $<\mathrm{t}$ tabel atau signifikansi $\mathrm{t}>0.1$ maka $\mathrm{H}_{0}$ diterima. Artinya variabel independen tidak berpengaruh signifikan terhadap variabel dependen. 
2. Jika $\mathrm{t}$ hitung $>\mathrm{t}$ table atau signifikansi $\mathrm{t}<0.1$ maka $\mathrm{H}_{0}$ ditolak. Artinya variabel independen berpengaruh signifikan terhadap variabel dependen.

\section{Hasil dan Pembahasan}

III.1. Obyek Penelitian

Jumlah perusahaan sektor pertanian yang telah memenuhi kriteria pengambilan sampel sebanyak 11 perusahaan. Daftar nama-nama perusahaan tersebut dapat dilihat pada Tabel 1.

Tabel 1.Daftar nama perusahaan sektor pertanian (sampel)

\begin{tabular}{cllll}
\hline No & \multicolumn{1}{c}{ Nama Perusahaan } & Kode & \multicolumn{1}{c}{ Tanggal Berdiri } & \multicolumn{1}{c}{ Tanggal Listing } \\
\hline 1 & Citra Kebun Raya Agri Tbk & CKRA & 19 September 1990 & 19 Mei 1999 \\
2 & Astra Agro Lestari Tbk & AALI & 03 Oktober 1988 & 09 Desember 1997 \\
3 & Bakrie Sumatera Plantations Tbk & UNSP & 17 Februari 1911 & 06 Maret 1990 \\
4 & PP London Sumatra Indonesia & LSIP & 18 Desember 1962 & 05 Juli 1996 \\
5 & Sinar Mas Agro Resources And Technology Tbk & SMAR & 18 Juni 1962 & 20 November 1992 \\
6 & Tunas Baru Lampung Tbk & TBLA & 22 Desember 1970 & 11 Februari 2000 \\
7 & PT Indo Setu Bara Resources Tbk & CPDW & 25 November 1970 & 18 Juni 1990 \\
8 & Central Proteinaprima Tbk & CPRO & 30 April 1980 & 28 November 2006 \\
9 & Dharma Samudera Fishing Industries Tbk & DSFI & 02 Oktober 1973 & 24 Maret 2000 \\
10 & Inti Agri Resources Tbk & IIKP & 16 Maret 1999 & 14 Oktober 2002 \\
11 & Bumi Teknokultura Unggul Tbk & BTEK & 06 Juni 2001 & 14 Mei 2004 \\
\hline Sumber: Fact Book BEI Tahun 2007-2011 & & &
\end{tabular}

Sumber: Fact Book BEI Tahun 2007-2011

\section{III.2. Analisis Data Deskriptif}

Berdasarkan data laporan keuangan dari sebelas perusahaan periode tahun 2007 sampai dengan tahun 2011, maka dapat dihitung rasio-rasio keuangan yang digunakan dalam penelitian ini. Rasio ini meliputi Kebijakan Hutang (Long Term Debt to Equity), Kepemilikan Institusional (Institutional Investor), Struktur Aset (Fixed Asset Ratio), Profitabilitas (Return on Asset), dan Pertumbuhan Perusahaan (Growth). Selanjutnya diperoleh gambaran sebagaimana yang ditunjukkan pada Tabel 2.

Tabel 2. Deskripsi statistik variable

\begin{tabular}{lccccc}
\hline \multicolumn{1}{c}{ Variabel } & $\begin{array}{c}\text { Jumlah Sampel } \\
\text { Penelitian }\end{array}$ & Minimum & Maximum & Rata-rata & $\begin{array}{c}\text { Standar } \\
\text { Deviasi }\end{array}$ \\
\hline Kebijakan Hutang & 30 & 0.13 & 144.33 & 43.2495 & 40.97300 \\
Kepemilikan Institusional & 30 & 27.05 & 97.02 & 67.8983 & 21.54560 \\
Struktur Asset & 30 & 0.02 & 46.03 & 28.2279 & 11.28238 \\
Profitabilitas & 30 & -29.27 & 40.35 & 6.5993 & 14.45341 \\
Pertumbuhan Perusahaan & 30 & -22.45 & 51.79 & 12.9672 & 16.26425 \\
\hline
\end{tabular}

Sumber: Output IBM SPSS Statistics 20.0

\section{III.3. Uji Asumsi Klasik}

Penelitian ini menggunakan analisis regresi linier berganda untuk menguji hipotesis. Namun demikian, terlebih dahulu dilakukan pengujian mengenai ada tidaknya penyimpangan data sampel terhadap asumsi klasik yang diperlukan untuk mendapatkan model regresi yang baik.

1. Uji Normalitas

Uji normalitas yang digunakan dalam penelitian ini adalah uji Kolmogorof Smirnov (K-S). Output SPSS uji K-S pada Tabel 3 menunjukkan bahwa dengan sampel 
sebanyak 55 dihasilkan nilai Sig. K-S pada variabel LDER, INST, FAR, ROA, dan GROWTH secara berturut-turut adalah sebesar 0.000; 0.341;0.348; 0.109 dan 0.000. Sehingga dapat disimpulkan bahwa variabel INST, FAR, dan ROA sudah terdistribusi dengan normal, sedangkan variabel LDER dan GROWTH tidak terdistribusi dengan normal. Model regresi yang baik mensyaratkan semua variabel yang digunakan untuk membangun regresi harus terdistribusi dengan normal, sehingga perlu mengeluarkan beberapa sample untuk menormalkan data pada variabel LDER dan GROWTH. Output SPSS uji K-S setelah tidak mengikutsertakan data outlier dalam membangun model regresi disajikan pada Tabel 4.

Tabel 3. One-Sample Kolmogorov-Smirnov Test

\begin{tabular}{lccccc}
\hline \multicolumn{1}{c}{ Keterangan } & $\begin{array}{c}\text { Kebijakan } \\
\text { Hutang }\end{array}$ & $\begin{array}{c}\text { Kepemilikan } \\
\text { Institusional }\end{array}$ & Struktur Asset & Profitabilitas & $\begin{array}{c}\text { Pertumbuhan } \\
\text { Perusahaan }\end{array}$ \\
\hline Jumlah Sampel & 55 & 55 & 55 & 55 & 55 \\
Nilai signifikan & 0.000 & 0.341 & 0.348 & 0.109 & 0.000 \\
Kolmogorov-Smirnov & & & & & \\
\hline
\end{tabular}

Sumber: Output IBM SPSS Statistics 20.0

Tabel 4. One-Sample Kolmogorov-Smirnov Test tanpa data outlier

\begin{tabular}{lccccc}
\hline \multicolumn{1}{c}{ Keterangan } & $\begin{array}{c}\text { Kebijakan } \\
\text { Hutang }\end{array}$ & $\begin{array}{c}\text { Kepemilikan } \\
\text { Institusional }\end{array}$ & Struktur Asset & Profitabilitas & $\begin{array}{c}\text { Pertumbuhan } \\
\text { Perusahaan }\end{array}$ \\
\hline Jumlah Sampel & 30 & 30 & 30 & 30 & 30 \\
Nilai signifikan & 0.173 & 0.627 & 0.220 & 0.742 & 0.721 \\
Kolmogorov-Smirnov & & & & & \\
\hline
\end{tabular}

Sumber: Output IBM SPSS Statistics 20.0

Tabel 4 menunjukkan bahwa semua variabel sudah memiliki nilai Sig. K-S melebihi batas tingkat signifikan yang ditetapkan yaitu 0.1 , sehingga dapat disimpulkan bahwa data masing-masing variabel tersebut sudah terdistribusi dengan normal.

\section{Uji Multikolinieritas}

Uji multikolinieritas bertujuan untuk melihat apakah dalam suatu model regresi ditemukan adanya korelasi antar variabel bebas (independen). Uji multikolinieritas yang digunakan dalam penelitian ini menggunakan variance inflation factor (VIF) dan mengamati nilai tolarance. Hasil uji multikolinieritas ditampilkan pada Tabel 5.

Tabel 5. Hasil uji multikolinieritas

\begin{tabular}{lcc}
\multicolumn{1}{c}{ Variabel } & Tolerance & VIF \\
\hline Kepemilikan Institusional & 0.853 & 1.172 \\
Struktur Aset & 0.907 & 1.103 \\
Profitabilitas & 0.610 & 1.639 \\
Pertumbuhan Perusahaan & 0.609 & 1.643 \\
\hline
\end{tabular}

Sumber: Output IBM SPSS Statistics 20.0

Tabel 5 menunjukkan bahwa masing-masing variabel independen memiliki nilai Variance Inflation Factor (VIF) tidak lebih dari 10 dan nilai Tolerance tidak kurang dari 0,1 sehingga dapat disimpulkan bahwa data masing-masing variabel independen terbebas dari asumsi klasik multikolinieritas. Maka hasil uji mengindikasikan bahwa dalam model regresi tidak ditemukan adanya korelasi antar variabel independen. 


\section{Uji Heteroskedastisitas}

Uji heteroskedastisitas bertujuan untuk melihat apakah dalam model regresi terjadi ketidaksamaan varian dari residual satu pengamatan ke pengamatan lain. Uji heteroskedastisitas menggunakan grafik plot antara nilai variabel dependen yaitu ZPRED dengan residualnya SPESID. Berikut hasil uji heteroskedastisitas yang ditampilkan pada Gambar 2.

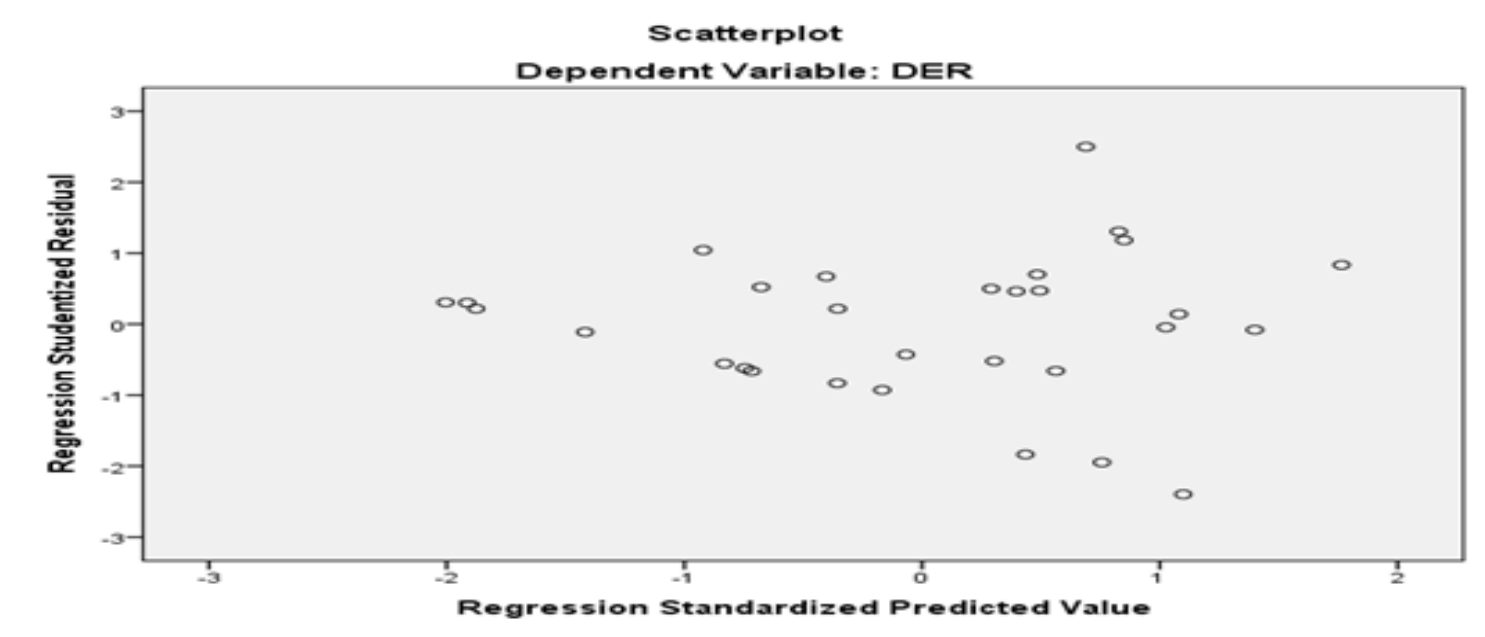

Gambar 2. Hasil uji heteroskedastisitas

Berdasarkan Gambar 2 hasil uji heteroskedastisitas menunjukkan bahwa tidak ada pola tertentu seperti bergelombang atau melebar kemudian menyempit dan melebar kembali. Hal ini mengindikasikan bahwa dalam model regresi penelitian ini tidak terjadi heteroskedastisitas.

\section{Uji Autokorelasi}

Uji autokorelasi bertujuan untuk menguji apakah dalam model regresi terjadi korelasi antara kesalahan pengganggu pada periode $t$ dengan kesalahan pengganggu pada periode t-1. Uji autokorelasi yang digunakan adalah uji Durbin-Watson (DW). Berikut hasil uji heteroskedastisitas yang ditampilkan pada Tabel 6.

Tabel 6. Hasil uji Durbin Watson

\begin{tabular}{cc}
\hline Model & Durbin-Watson \\
\hline Regression & 1.747 \\
\hline
\end{tabular}

Sumber: Output IBM SPSS Statistics 20.0

Hasil uji Durbin-Watson dalam Tabel 6 menunjukkan nilainya DW sebesar 1.747 di mana variabel $(k)$ dalam penelitian ini sebesar 4 dan jumlah sampel (n) sebesar 30, maka didapatkan nilai batas atas $d l=1.140$ dan batas bawah $d u=1.740$. Nilai uji DurbinWatson (DW) sebesar 1.747 memperlihatkan bahwa nilai DW berada di antara batas atas (du) sebesar 1.740 dan batas atas (4-du) sebesar 2.26 sehingga dalam model regresi penelitian ini terbebas dari asumsi klasik autokorelasi. 


\section{III.4. Uji Hipotesis}

1. Uji Signifikan Simultan (Uji Statistik F)

Hasil uji signifikan simultan (uji statistik F) penelitian ini menunjukkan nilai $\mathrm{F}$ hitung sebesar 4.184 lebih besar dari $F$ tabel sebesar 2.184 dan nilai signifikan $F$ sebesar 0.010 lebih kecil dari 0.1. Hasil ini menunjukkan bahwa $\mathrm{H}_{0}$ ditolak dan $\mathrm{H}_{5}$ diterima atau dengan kata lain variabel kepemilikian institusional, variabel struktur asset, variabel profitabilitas, dan variabel pertumbuhan perusahaan secara bersamasama memiliki pengaruh yang signifikan terhadap variabel kebijakan hutang. Hasil uji signifikan simultan disajikan pada Tabel 7.

Tabel 7. Hasil uji signifikan simultan (uji statistik F)

\begin{tabular}{cccc}
\hline Model & Uji Statistik F & Nilai Signifikan & Adjusted R quare \\
\hline Regresi & 1.747 & 0.010 & 0.305 \\
\hline
\end{tabular}

Sumber: Output IBM SPSS Statistics 20.0

Pada Tabel 7, nilai Adjusted R Square adalah sebesar 0.305 atau 30.5\%. Hal ini menjelaskan bahwa sebesar 30,5\% variabel Kebijakan Hutang (LDER) dijelaskan oleh variabel kepemilikan institusional (INST), variabel struktur aset (FAR), variabel profitabilitas (ROA), dan variabel pertumbuhan perusahaan (GROWTH), sedangkan sisanya sebesar $69.5 \%$ dijelaskan oleh variabel-variabel lain di luar model. Hal ini menunjukkan bahwa kebijakan hutang (LDER) pada perusahaan-perusahaan sektor pertanian yang terdaftar di Bursa Efek Indonesia periode 2007-2011 tidak hanya dipengaruhi oleh variabel kepemilikan institusional, variabel struktur aset, variabel profitabilitas, dan variabel pertumbuhan perusahaan.

\section{Uji Signifikan Parameter Individual (Uji Statistik t)}

Hasil uji signifikan parameter individual (uji statistik t) tersaji pada Tabel 8. Berdasarkan pada Tabel 7 (uji signifikan simultan) dan Tabel 8 (uji signifikan parameter individual), maka dapat disusun persamaan regresi berganda sebagai berikut :

$$
\mathrm{LDER}=52.715-0.632 \mathrm{INST}+1.019 \mathrm{FAR}-1.198 \mathrm{ROA}+0.972 \mathrm{GROWTH} \ldots \ldots \text { (7) }
$$

Tabel 8. Hasil uji signifikan parameter individual (uji statistik t)

\begin{tabular}{lccc}
\hline \multicolumn{1}{c}{ Variabel } & Unstandardized Coefficients B & Uji Statistik t & p-value \\
\hline (Constant) & 52.715 & 1.716 & 0.099 \\
Kepemilikan Institusional & -0.632 & -1.984 & 0.058 \\
Struktur Aset & 1.019 & 1.726 & 0.097 \\
Profitabilitas & -1.198 & -2.132 & 0.043 \\
Pertumbuhan Perusahaan & 0.972 & 1.946 & 0.063 \\
\hline
\end{tabular}

Sumber: Output IBM SPSS Statistics 20.0

Tabel 8 menunjukkan bahwa secara parsial variabel kepemilikan institusional, variabel struktur aset, variabel profitabilitas, dan variabel pertumbuhan perusahaan memiliki pengaruh yang signifikan terhadap kebijakan hutang. Hal ini dapat dijelaskan melalui uji hipotesis sebagai berikut : 
a. Uji Hipotetsis Kepemilikan Institusional $\left(\mathrm{H}_{1}\right)$

Tabel 8 menunjukkan nilai $t$ hitung sebesar -1.984 lebih besar dari $t$ tabel sebesar -1.706 dan nilai signifikan t variabel kepemilikan institusional sebesar 0.058 kurang dari 0.1. Hasil ini menunjukkan bahwa $\mathrm{H}_{0}$ ditolak dan $\mathrm{H}_{1}$ diterima atau dengan kata lain kepemilikan institusional berpengaruh signifikan terhadap kebijakan hutang. Nilai beta pada kepemilikan institusional adalah -0.632 yang menunjukkan hubungan negatif sebesar $0.632 \%$. Hal ini memperlihatkan bahwa faktor kepemilikan institusional memiliki pengaruh yang signifikan dan berhubungan negatif terhadap kebijakan hutang. Namun demikian, nilai beta sebesar -0.632 menunjukkan bahwa faktor kepemilikan institusional memiliki pengaruh yang cukup rendah dibandingkan faktor pertumbuhan perusahaan, struktur aset, dan profitabilitas dalam model regresi linier berganda, sebagaimana yang ditunjukkan pada Gambar 3.

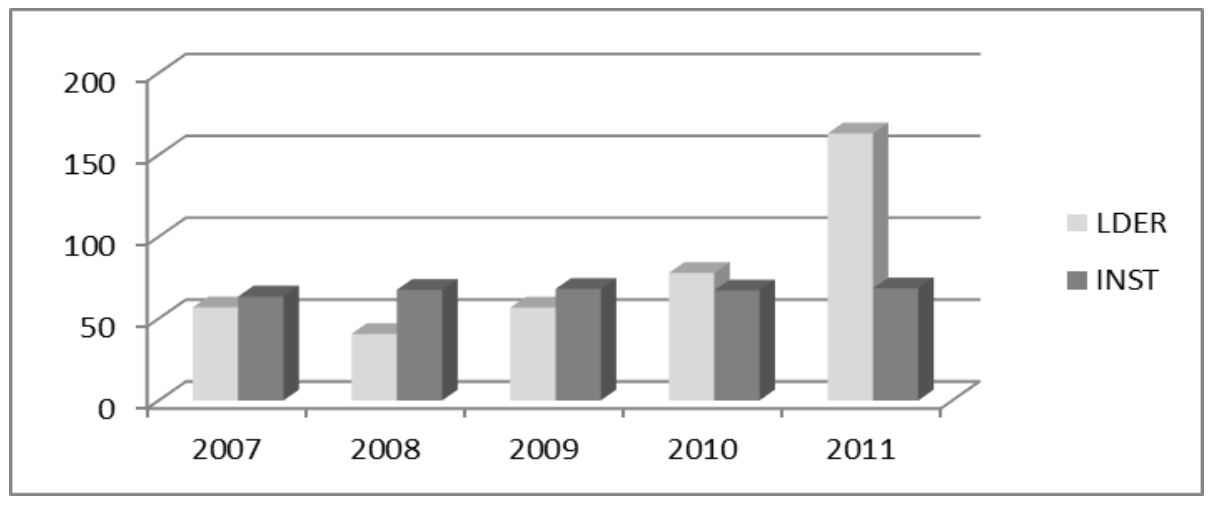

Gambar 3. Pengaruh INST terhadap LDER

Berdasarkan Gambar 3, pengaruh kepemilikan institusional (INST) terhadap kebijakan hutang (LDER) menunjukkan bahwa pada tahun 2007 sampai dengan tahun 2011 terjadi peningkatan pada INST yang diikuti dengan penurunan LDER pada tahun 2008, meskipun pada tahun 2009 terjadi peningkatan hutang namun masih di bawah besarnya hutang pada tahun 2007 sehingga dengan kata lain kepemilikan institusional dapat menekan pendanaan hutang. Pada tahun 2010 sampai dengan tahun 2011 telah terjadi peningkatan hutang yang tinggi, ini menunjukkan bahwa dalam model regresi linier berganda untuk faktor kepemilikan institusional memiliki pengaruh yang rendah sebesar $-0.632 \%$ terhadap kebijakan hutang. Secara keseluruhan hal ini menjelaskan bahwa rata-rata kepemilikan saham perusahaan pertanian yang dimiliki oleh institusi dalam jumlah besar memiliki pengaruh yang signifikan dalam menekan penggunaan hutang yang berlebih oleh pihak manajemen yang dapat memunculkan risiko kebangkrutan perusahaan.

b. Uji Hipotesis Struktur Aset $\left(\mathrm{H}_{2}\right)$

Berdasarkan pada Tabel 8, nilai t hitung sebesar 1.726 lebih besar dari t tabel sebesar 1.706 dan nilai signifikan t variabel struktur aset sebesar 0.097 kurang dari 0.1. Hasil ini menunjukkan bahwa $\mathrm{H}_{0}$ ditolak dan $\mathrm{H}_{1}$ diterima, dengan kata lain struktur aset berpengaruh signifikan terhadap kebijakan hutang. Nilai beta pada kepemilikan institusional adalah 1.019 yang menunjukkan hubungan positif sebesar 
1.019\%. Hal ini memperlihatkan bahwa faktor struktur aset memiliki pengaruh yang signifikan dan berhubungan positif terhadap kebijakan hutang. Nilai beta sebesar 1.019 menunjukkan bahwa faktor struktur aset memiliki pengaruh yang cukup besar dibandingkan faktor kepemilikan institusional dan faktor pertumbuhan perusahaan dalam model regresi linier berganda, sebagaimana yang ditunjukkan pada Gambar 4.

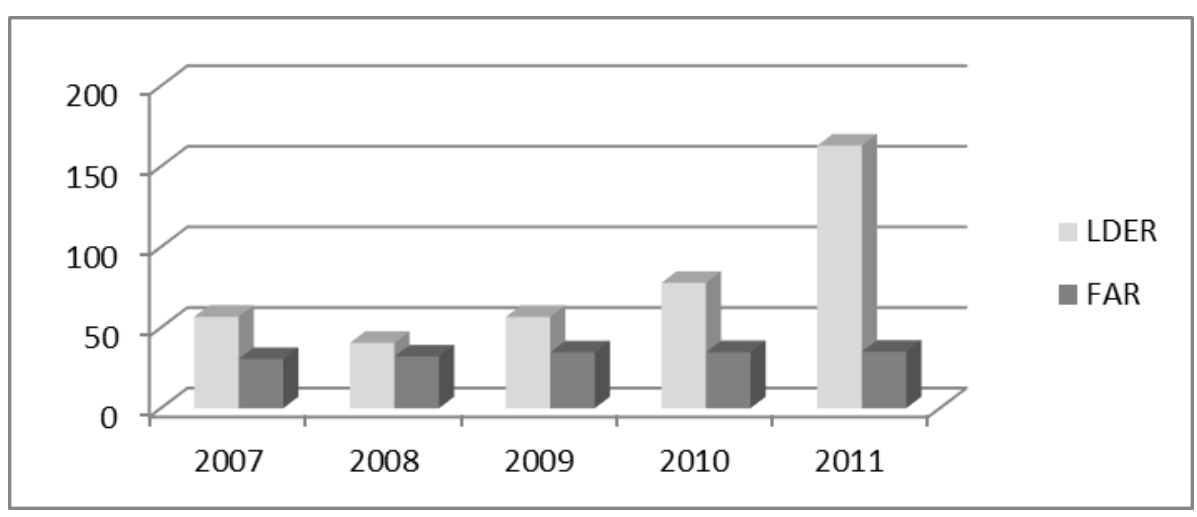

Gambar 4. Pengaruh FAR terhadap LDER

Gambar 4 menunjukkan bahwa secara keseluruhan data dari tahun 2007 hingga tahun 2011, terjadi peningkatan pada FAR yang diikuti dengan peningkatan LDER. Peningkatan FAR dan LDER membuktikan bahwa meningkatnya fixed asset membuat perusahaan dapat menggunakan hutang yang lebih banyak, atau dengan kata lain strutur aset memiliki hubungan positif terhadap kebijakan hutang. Hal ini menjelaskan bahwa rata-rata aktiva tetap perusahaan pertanian yang terus meningkat memiliki pengaruh yang signifikan terhadap peningkatan penggunaan hutang, di mana aktiva tetap sebagai jaminan membuat perusahaan pertanian lebih mudah dalam mendapatkan pinjaman hutang yang lebih besar.

c. Uji Hipotesis Profitabilitas $\left(\mathrm{H}_{3}\right)$

Berdasarkan pada Tabel 8, nilai t hitung sebesar -2.132 lebih besar dari t tabel sebesar -1.706 dan nilai signifikan t variabel profitabilitas sebesar 0.043 kurang dari 0 ,1. Hasil ini menunjukkan bahwa $H_{0}$ ditolak dan $H_{1}$ diterima yang artinya profitabilitas berpengaruh signifikan terhadap kebijakan hutang. Nilai beta pada profitabilitas adalah -1.198 menunjukkan hubungan negatif sebesar $1.198 \%$ yang memperlihatkan bahwa faktor profitabilitas memiliki pengaruh yang signifikan dan berhubungan negatif terhadap kebijakan hutang. Profitabilitas memiliki pengaruh yang lebih besar dibandingkan faktor kepemilikan institusional, pertumbuhan perusahaan, dan struktur aset dalam model regresi linier berganda, sebagaimana ditunjukkan pada Gambar 5.

Gambar 5 menunjukkan bahwa dari tahun 2007 sampai dengan tahun 2011, terjadi penurunan ROA yang diikuti dengan peningkatan LDER. Penurunan ROA dan peningkatan LDER membuktikan bahwa menurunnya tingkat keuntungan bersih perusahaan membuat perusahaan mengambil kebijakan pendanaan modal dengan hutang. Hal ini menjelaskan bahwa rata-rata tingkat keuntungan perusahaan pertanian yang rendah memiliki pengaruh yang signifikan terhadap peningkatan 
penggunaan hutang. Keterbatasan dana dari hasil laba perusahaan tidak dapat memenuhi kebutuhan dana perusahaan sehingga perusahaan merasa perlu menggunakan hutang untuk memenuhi kebutuhan dana perusahaan.

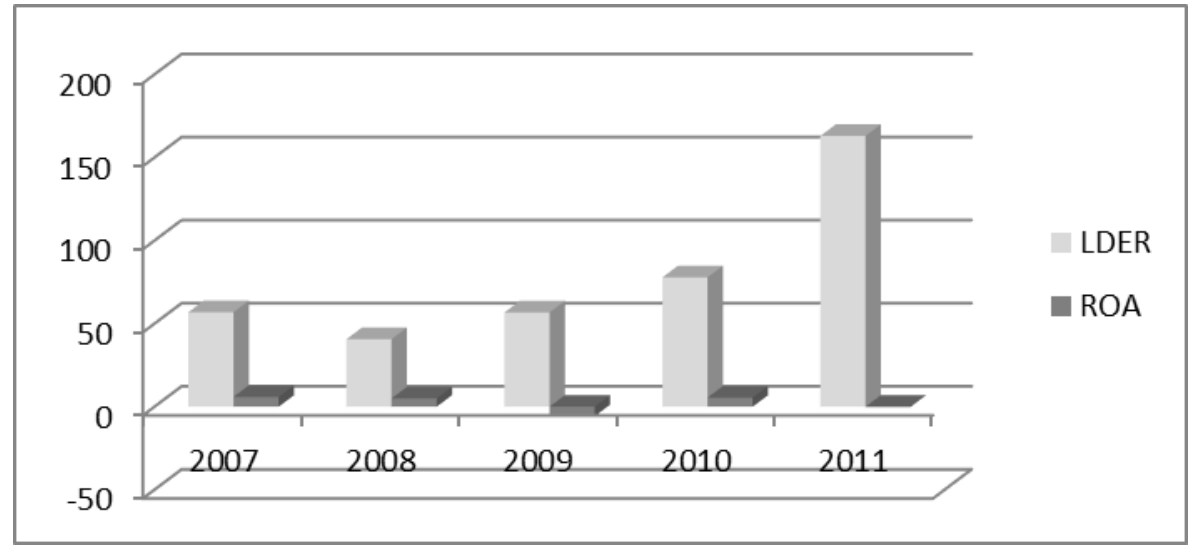

Gambar 5. Pengaruh ROA terhadap LDER

d. Uji Hipotesis Pertumbuhan Perusahaan $\left(\mathrm{H}_{4}\right)$

Berdasarkan pada Tabel 8, nilai t hitung sebesar 1.946 lebih besar dari t tabel sebesar 1.706 dan nilai signifikan t variabel pertumbuhan perusahaan sebesar 0.063 kurang dari 0.1. Hasil ini menunjukkan bahwa $\mathrm{H}_{0}$ ditolak dan $\mathrm{H}_{1}$ diterima atau dengan kata lain pertumbuhan perusahaan berpengaruh signifikan terhadap kebijakan hutang. Nilai beta pada pertumbuhan perusahaan adalah 0.972 yang menunjukkan hubungan positif sebesar $0.972 \%$. Hal ini memperlihatkan bahwa faktor pertumbuhan perusahaan memiliki pengaruh yang signifikan dan berhubungan positif terhadap kebijakan hutang. Faktor pertumbuhan perusahaan memiliki pengaruh yang rendah dibandingkan faktor struktur aset dan faktor profitabiltas dalam model regresi linier berganda, sebagaimana ditunjukkan pada Gambar 6.

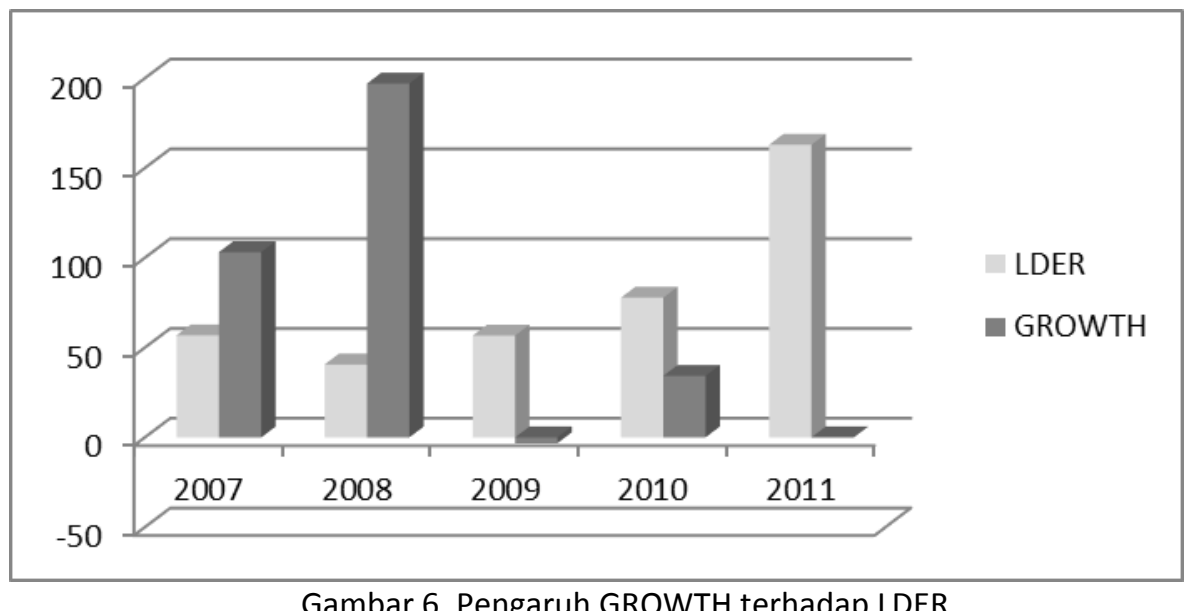

Gambar 6 menunjukkan bahwa pada dari 2007 sampai dengan tahun 2008 terjadi peningkatan pada GROWTH yang diikuti dengan sedikit penurunan LDER pada tahun 2008. Hal ini membuktikan bahwa hasil nilai beta sebesar $0.972 \%$ 
menunjukkan pertumbuhan perusahan memiliki pengaruh yang rendah terhadap kebijakan hutang. Namun demikian selama 3 tahun berturut-turut pada tahun 2009 sampai dengan tahun 2011 terjadi peningkatan GROWTH yang diikuti dengan peningkatan LDER meskipun pada tahun 2011 sedikit mengalami penurunan, namun masih di atas GROWTH tahun 2009. Hal ini secara keseluruhan menjelaskan bahwa rata-rata pertumbuhan perusahaan pertanian yang meningkat memiliki pengaruh signifikan dalam meningkatnya penggunaan hutang perusahaan, dikarenakan peningkatan pertumbuhan perusahaan pertanian mendorong kebutuhan dana yang besar sehingga penggunaan hutang dapat menjadi pilihan tepat dalam memenuhi kebutuhan dana perusahaan.

\section{Kesimpulan}

Hasil pengujian signifikan simultan (uji statistik F) menunjukkan bahwa faktor kepemilikan institusional, struktur aset, profitabilitas, dan pertumbuhan perusahaan secara bersama-sama signifikan mempengaruhi kebijakan hutang. Hasil pengujian signifikan parameter individual (uji statistik T) menunjukkan bahwa 1) faktor kepemilikan institusional signifikan dan berhubungan negatif terhadap penggunaan hutang atau dengan kata lain, ketika meningkatnya kepemilikan saham perusahaan oleh pihak institusi dalam jumlah besar, maka pemilik saham mayoritas dapat memberikan kebijakan dengan menekan penggunaan hutang secara berlebih yang dapat memunculkan risiko kebangkrutan; 2) Faktor struktur aset signifikan dan berhubungan positif terhadap penggunaan hutang atau dengan kata lain, ketika meningkatnya jumlah aktiva tetap perusahaan yang dapat digunakan sebagai jaminan, memberikan kesempatan lebih mudah bagi perusahaan untuk mendapatkan pinjaman dalam jumlah besar sehingga meningkat juga penggunaan hutang perusahaan; 3) Faktor profitabilitas signifikan dan berhubungan negatif terhadap penggunaan hutang atau dengan kata lain, ketika keuntungan (profit) perusahaan meningkat maka kebutuhan dana perusahaan sedikitnya dapat dipenuhi oleh laba sehingga penggunaan hutang sebagai tambahan dana eksternal dapat ditekan; 4) Faktor pertumbuhan perusahaan signifikan dan berhubungan positif terhadap penggunaan hutang atau dengan kata lain, ketika perusahaan melakukan suatu ekspansi maka menandakan adanya kebutuhan dana yang besar sehingga mendorong perusahaan untuk menggunakan hutang sebagai alternatif tambahan sumber dana eksternal. Berdasarkan besarnya nilai Beta $(\beta)$ hasil uji signifikan parameter individual bahwa dalam model regresi berganda faktor profitabilitas memiliki pengaruh yang sangat besar terhadap kebijakan hutang, kemudian faktor struktur aset memiliki pengaruh yang cukup besar terhadap kebijakan hutang, selanjutnya faktor pertumbuhan perusahaan memiliki pengaruh yang cukup rendah terhadap kebijakan hutang, dan terakhir faktor kepemilikan institusional memiliki pengaruh yang sangat rendah terhadap kebijakan hutang.

\section{Daftar Pustaka}

Brigham EF, Gapenski IC. 1996. Intermediate Financial Management, 5th ed. New York (US): The Dryden Press. 
Ghozali I. 2005. Aplikasi Analisis Multivariate dengan Program SPSS. Semarang (ID): Badan Penerbit UNDIP.

Hapsari LI. 2010. Analisis Faktor-faktor yang mempengaruhi struktur modal perusahaan manufaktur yang terdaftar di Bursa Efek Indonesia periode 20062008 [skripsi]. Semarang (ID): Universitas Diponegoro.

Ismiyanti F, Hanafi MM. 2003. Kepemilikan manajerial, kepemilikan institusional, risiko kebijakan utang dan kebijakan dividen. Analisis Simulatan Prosiding Simposium Nasional Akuntansi VI 16-17 Oktober, hlm 160-177.

Lestari. 2001. Analisis faktor-faktor yang berpengaruh terhadap kebijakan hutang perusahaan manufaktur di BEJ dalam konteks agency theory [tesis]. Semarang (ID): Universitas Diponegoro.

Mardiyanto H. 2009. Inti Sari Manajemen Keuangan. Jakarta (ID): PT Gramedia Widiasarana.

Soesetio Y. 2008. Kepemilikan manajerial dan institusional, kebijakan dividen, ukuran perusahaan, struktur aktiva dan profitabilitas terhadap kebijakan hutang. Jurnal Keuangan dan Perbankan, 12(3): 384-398.

www.idx.co.id (diakses 07 Oktober 2012)

Yeniatie, Destriana N. 2010. Faktor-faktor yang mempengaruhi kebijakan hutang pada perusahaan nonkeuangan yang terdaftar di Bursa Efek Indonesia. Jurnal Bisnis dan Akuntansi, 12(1): 1-16. 